\title{
Local extinction of sharks of genus Carcharias Rafinesque, 1810 (Elasmobranchii, Odontaspididae) in the eastern Pacific Ocean
}

\author{
Alberto L. Cione \\ Jorge A. Mennucci \\ Fernando Santalucita \\ Carolina Acosta Hospitaleche
}

\author{
División Paleontología Vertebrados, Museo de La Plata, \\ 1900 La Plata, Argentina. CONICET \\ acione@museo.fcnym.unlp.edu.ar \\ jaumennucci@hotmail.com \\ santalucita@yahoo.com.ar \\ acostacaro@museo.fcnym.unlp.edu.ar
}

\begin{abstract}
Fossil record has shown that the genus Carcharias and probably species C. taurus Rafinesque, 1810 occupied the western coast of South America during the Miocene and part of the Pliocene. The genus is absent in the area today. It is suggested that its local extinction was the consequence of a drop of global temperatures during the middle Pliocene and Pleistocene and the coeval lowering of sea level that shrinked the area of distribution to the northern areas and provoked the disappearance of suitable environments when the shelf area became extremely reduced. After approximately $3 \mathrm{Ma}$ it would have not been possible for the species to migrate from the north to the region due to the establishment of the Panamanian isthmus.
\end{abstract}

Key words: Odontaspididae, Carcharias, Local extinction, Miocene, Pliocene, South America.

\section{RESUMEN}

Extinción local de tiburones del género Carcharias Rafinesque, 1810 (Elasmobranchii, Odontaspididae) en el Océano Pacífico oriental. El estudio del registro paleontológico indica que la distribución de Carcharias y posiblemente $C$. taurus Rafinesque, 1810, durante el Mioceno y parte del Plioceno, habría incluido la costa oeste de Sudamérica, donde hoy se encuentra ausente. Se propone que su extirpación de esta zona habría sido provocada por el abrupto descenso de las temperaturas durante el Plioceno medio y Pleistoceno y la consiguiente caída del nivel del mar, lo que habría reducido notablemente el ambiente de plataforma, hábitat natural de este taxón. Posteriormente a los $3 \mathrm{Ma}$ aproximadamente, al restablecerse el nivel del mar, la recolonización desde el norte no habría sido posible debido al establecimiento del istmo de Panamá.

Palabras claves: Odontaspididae, Carcharias, Extinción local, Mioceno, Plioceno, América del Sur. 


\section{INTRODUCTION}

Neoselachians sharks are included in the class Chondrichthyes, a very ancient clade which perhaps ranges from the Ordovician but certainly from the Devonian. Sharks, very important fishes in the economy of the sea today, include the most ancient vertebrate recent genera. A family of relatively large sharks, Odontaspididae, is known since the Aptian (early Cretaceous; Carcharias striatula (Dalinkevicius, 1935); Cappetta et al., 1993). Today it includes the genera Odontaspis Agassiz, 1838 and Carcharias. Genus Carcharias is monospecific today but it had several fossil species (Cappetta, 1987). Recent species C. taurus (Rafinesque, 1810) is wide-ranging in warm-temperate and tropical coastal waters of the Atlantic Ocean, Mediterranean Sea, and Indo-West Pacific Ocean butis absent from the Central Pacific and eastern Pacific oceans (Compagno, 2001; Lucifora et al., 2003; Fig. 1). However, the fossil record has shown that the distribution of the genus Carcharias and possibly the species $C$. taurus occupied the western coast of South America during the Miocene and at least part of the Pliocene. The World Conservation Union considers $C$. taurus as a vulnerable species today, with its populations seriously depleted (Compagno, 2001). It is critically endangered in New South Wales, Australia, after large numbers were killed in sports and commercial fisheries and by divers (Compagno, 2001). Cione and Azpelicueta (2002) described several cases of extirpation of fishes in the Atlantic Ocean. In this paper, the occurrence of genus Carcharias in the eastern Pacific is reviewed and a hypothesis for explaining its local extinction is proposed.

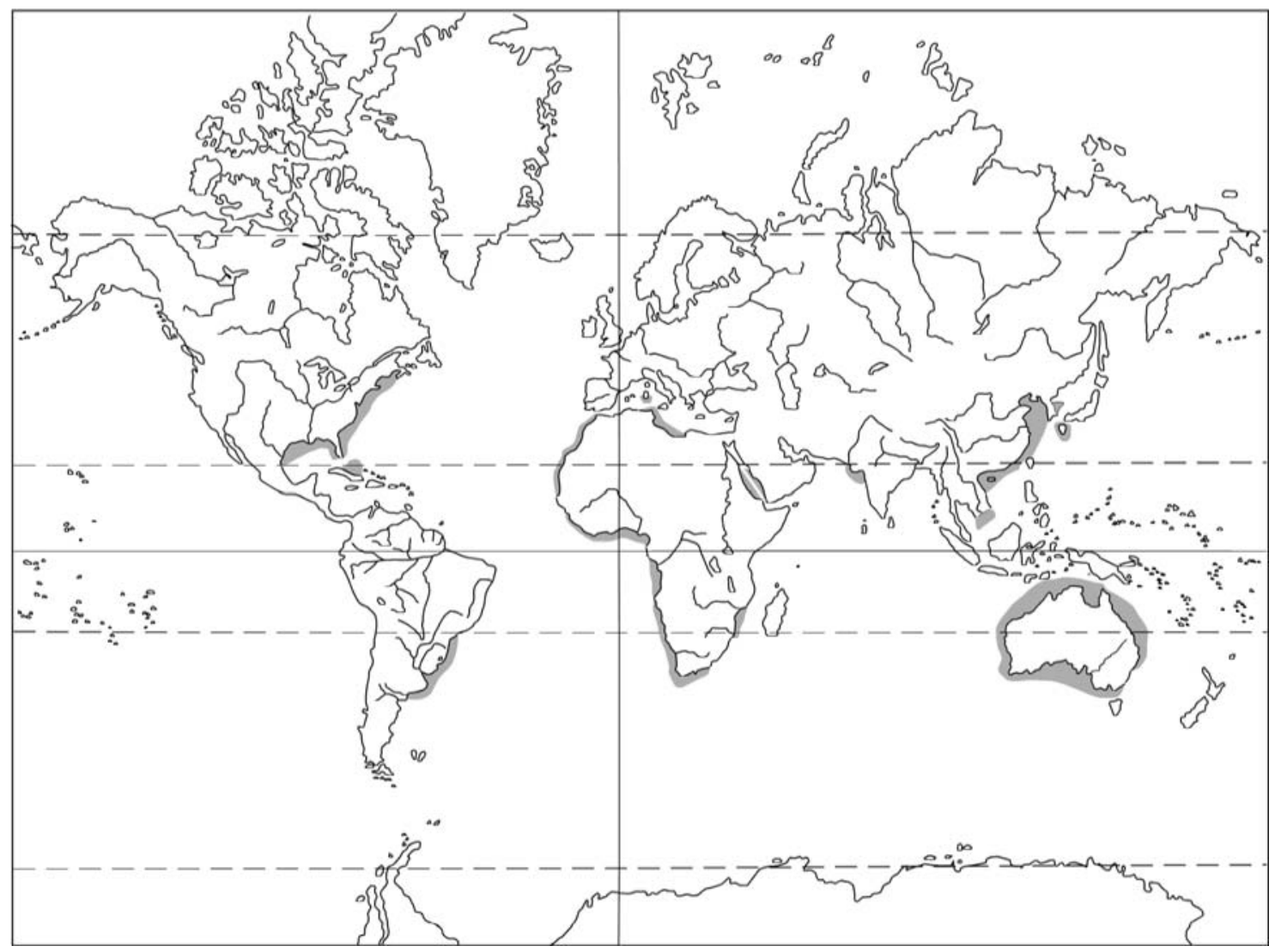

FIG. 1. Present distribution in gray of Carcharias taurus (Rafinesque, 1810, modified from Compagno, 2001). 


\section{OCCURRENCE IN THE SOUTHEASTERN PACIFIC DURING THE CENOZOIC}

Teeth that could correspond to the genera Striatolamia Glückman, 1964 or Carcharias (Rafinesque, 1810) were reported from Eocene beds in different localities (Lota, Lebu, Puchoco, Buen Retiro) of southern Chile (Oliver-Schneider, 1936; Arratia and Cione, 1996; Fig. 2). The material was not figured. Striatolamia traditionally was considered to be an Odontaspididae. However, Siverson (1995) suggested that it could pertain to another lamniform family, Mitsukurinidae. However, specimens certainly assignable to the odontaspidid genus Carcharias were described from Miocene to Pliocene beds (Fig. 2):

Carcharias acutissima (Agassiz, 1843), formerly described as Odontaspis acutissima, from transitional strata between Borbon and Onzole formations in Ecuador (Longbottom, 1979; Figs. 3-4). Both were formerly considered Miocene in age but presently are referred to the Pliocene (Aalto and Miller, 1999). The localities are CRB 123, a sea stack at Punta La Colorada $\left(0^{\circ} 37.6^{\prime} \mathrm{S}, 80^{\circ} 27.6^{\prime} \mathrm{W}\right)$ and $\mathrm{CRB} 123 \mathrm{~b}$ is the cliff at Punta La Gorda (0³8.2'S, 80²8'W).

Carcharias (as Synodontaspis White, 1931) aff. taurus, in the Sacaco vertebrate level (SAO) in the upper part of the Pisco Formation at Sacaco, Perú (near the Peruvian coast, $1^{\circ} 32$ 'S; de Muizon, 1981; de Muizon and DeVries, 1985). The material was identified as such (Cappetta, H., oral comm., 1983, to de Muizon) but not figured. The bearing level corresponds to the Anadara Zone and is Early Pliocene in age. A K-Ar date of 3.9 Ma was obtained in a tuff located several meters below the SAO level at Sacaco (de Muizon and DeVries, 1985). No unconformity is yet known between the tuff and SAO level so it can be reasonably assumed that the SAO level is late Early Pliocene (de Muizon and DeVries, 1985).

Carcharias cuspidata (Agassiz, 1843) has been identified in the Navidad Formation (Early Miocene), at about $150 \mathrm{~km}$ from Santiago, in the VI Region, Cardenal Caro Province, Central Chile (Suárez and Encinas, 2002).

Another occurrence of Carcharias sp., is from the Bahía Inglesa Formation in the Mina La Fosforita, Bahía Inglesa, Región de Atacama, Provincia de Copiapó,

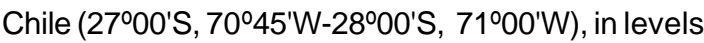
dated as Late Miocene-Middle Pliocene because of the presence of Carcharodon carcharias (Walsh and Hume, 2001; Suárez et al., 2004).

These records have demonstrated that individuals of Carcharias, probably C. taurus, inhabited the occidental shelf of South America until at least about 3-4 Ma. Besides, teeth assigned to the genus Carcharias have been reported from the Middle Miocene beds of California, USA ( $\mathrm{J}$. Bourdon $^{1}$ ).

\section{DISCUSSION AND CONCLUSIONS}

Odontaspidids were more widely distributed during the Cenozoic than today. They inhabited Antarctica until at least the Eocene and southern South America untilatleast the Early Miocene (Leriche, 1936; Cione et al., 1977; Long, 1992; Cione and Reguero, 1994; Arratia y Cione, 1996). The present authors studied morphological variations in different areas (Lucifora et al., 2003) and the distribution of Cenozoic specimens from different localities of Argentina (Cione et al., 2000). Distribution of some fishes is hard to explain according to vicariance and migration. However, their extirpation from high latitude cold seas is explained because of the global temperature drop during the late Cenozoic (Cione, 1978; Cione and Azpelicueta, 2002).

The distribution of Carcharias taurus is patchy today (Lucifora et al., 2003). The species is more frequent in relatively temperate areas although it also occurs in some equatorial waters (Fig. 1). It is an inshore and offshore, littoral shark that occurs from the intertidal less than $1 \mathrm{~m}$ deep down to at least $191 \mathrm{~m}$, and mostly at depths of 15 to $25 \mathrm{~m}$ (Compagno, 2001).

In South American coasts, several biogeographic marine provinces have been proposed. In the western coast, the Magallanian (from about $56^{\circ} \mathrm{S}$

${ }^{1}$ Active in 2006. Sharktooth Hill Miocene Sharks and Rays. http://www.elasmo.com/frameMe.html?file=paleo/sth/shrkhill.html\&menu=bin/menu_fauna-alt.html 
to $40^{\circ} \mathrm{S}$ ), Peruvian (from $40^{\circ} \mathrm{S}$ to $4-6^{\circ} \mathrm{S}$ ), and Panamic (from 4-6 ${ }^{\circ} \mathrm{S}$ to the North) provinces (López, 1964). In the eastern coast, the Magallanian (from about $56^{\circ} \mathrm{S}$ to about $42^{\circ} \mathrm{S}$ ), the Argentinean (from $41^{\circ} \mathrm{S}$ to $23^{\circ} \mathrm{S}$ ), and the Western Indian (from $23^{\circ} \mathrm{S}$ to the north) provinces (López, 1964). Carcharias taurus ranges from approximately Cabo Frio in Brazil to southern Buenos Aires Province in Argentina (Fig.1). Consequently, it is a typical element of the Argentinean province, of warm temperate waters (López, 1964). Compagno (2001, p. 59) includes C. taurus in the Magallanian province in the southern Atlantic; however we do not know of any record there. Carcharias taurus is a migratory shark in shelf areas (Compagno, 2001) that reaches the coast of Buenos Aires Province in the early summer and migrates northward in early fall.

The present oceanic circulation was established in the Miocene (Beu et al., 1997). A branch of the West Wind Drift, the Chile Current, runs along the South American western coast and carries Subantarctic water from the Austral Ocean approximately to $20^{\circ} \mathrm{S}$ where it turns west (Molina-Cruz and Herguera, 2002). Northwest of the backwater, along the Peruvian coast, flow towards the Equator also occurs: the Perú Current. However, according to faunal data, temperatures in Perú from the Miocene to the early Pliocene were higher than present (de Muizon and DeVries, 1985). Early Pleistocene assemblages indicate a rather sudden shift towards modern cooler conditions along the southern Peruvian coast (de Muizon and DeVries, 1985). Substantial cooling occurred in middle and high latitudes in the western North Pacific Ocean as well as the western North Atlantic Ocean between $3 \mathrm{Ma}$ and 2.4 Ma (Cronin and Dowsett, 1992; Tsuchi, 2002). During the Middle and Late Pleistocene temperature drop was very important in the area (Clapperton, 1993; Kimetal., 2002). Populations of sharks such as C. taurus could be displaced northerly looking for more optimal temperatures causing that the species distribution shrinked.

The continental shelf is presently extremely reduced in western South America (Fig. 2). At the latitude of Bahía Inglesa(Chile) or Sacaco(Perú), localities where Carcharias Miocene and Pliocene specimens were found, the present continental shelf is about $10 \mathrm{~km}$ and $20 \mathrm{~km}$ wide respectively. Oscillations between glacial and interglacial climate conditions over the past 3 million years ocassioned important sea level drops (Lambeck et al., 2002). The area between the present depth of 120-140 m (Rohling et al., 1998;
Lambecketal., 2002) and that of $200 \mathrm{~m}$ in the western South America surely represented an extremely reduced belt when the sea level was low. At the latitude of Bahía Inglesa and Sacaco, the belt could be as narrow as $1 \mathrm{~km}$ and $3 \mathrm{~km}$ respectively. On the contrary, when Carcharias inhabited the area during the Miocene and Pliocene, sea level was higher and shelf related organisms had a relatively wider area to inhabit (for instance, in Ecuador, where marine localities of this type and age are $20 \mathrm{~km}$ from the present coast; Bianucci et al., 1993). Reduction of the habitat occasioned by sea-level drops severely altered the surface area of ecologically critical zones over the continental shelves and generate important population stress (Smith et al. , 2001). In western South America, the suitable habitat for a shelf shark such as Carcharias taurus was destroyed by the sea drop. It is considered that this drove the species to local extinction after attaining its extinction point.

During the interglacial periods, when the sea level rised, recolonization from the north was not possible because the Panamanian isthmus was already established (3.7-3 Ma, perhaps later; Duque-Caro, 1990; Cione and Tonni, 1995; Hagelberg, 1996; Ibaraki, 1997).

Recolonization from the Atlantic ocean was also not possible through the Cape Horn area due to the low temperatures in the Drake area (contrary the opinion of Reif and Saure, 1987).

Apparently, the higher temperatures that occurred during the interglacial periods in the Pleistocene have not been enough to permit a transit from the Atlantic to the Pacific oceans (Moy et al., 2002). Local temperature and productivity variations did not altered the biogeographic situation (Loubere, 2002).

Extirpation (or remarkable reduction in distribution area) due to causes different from the global Cenozoic cooling trend is known from the Atlantic ocean for the shark families Heterodontidae, Pristiophoridae and the hemigaleid genus Hemipristis Agassiz, 1843, the teleost family Oplegnathidae, and the mammalian families Dugongidae and Monachinae (Cione and Azpelicueta, 2002). In Chile, there are several nominal selachian taxa reported (without description or illustration) from the Bahía Inglesa and Navidad formations that do not inhabit the eastern Pacific ocean (Suárez et al., 2002; Suárez and Encinas, 2002; Suárez et al., 2004). They could correspond to additional pseudoextinctions in the area. 


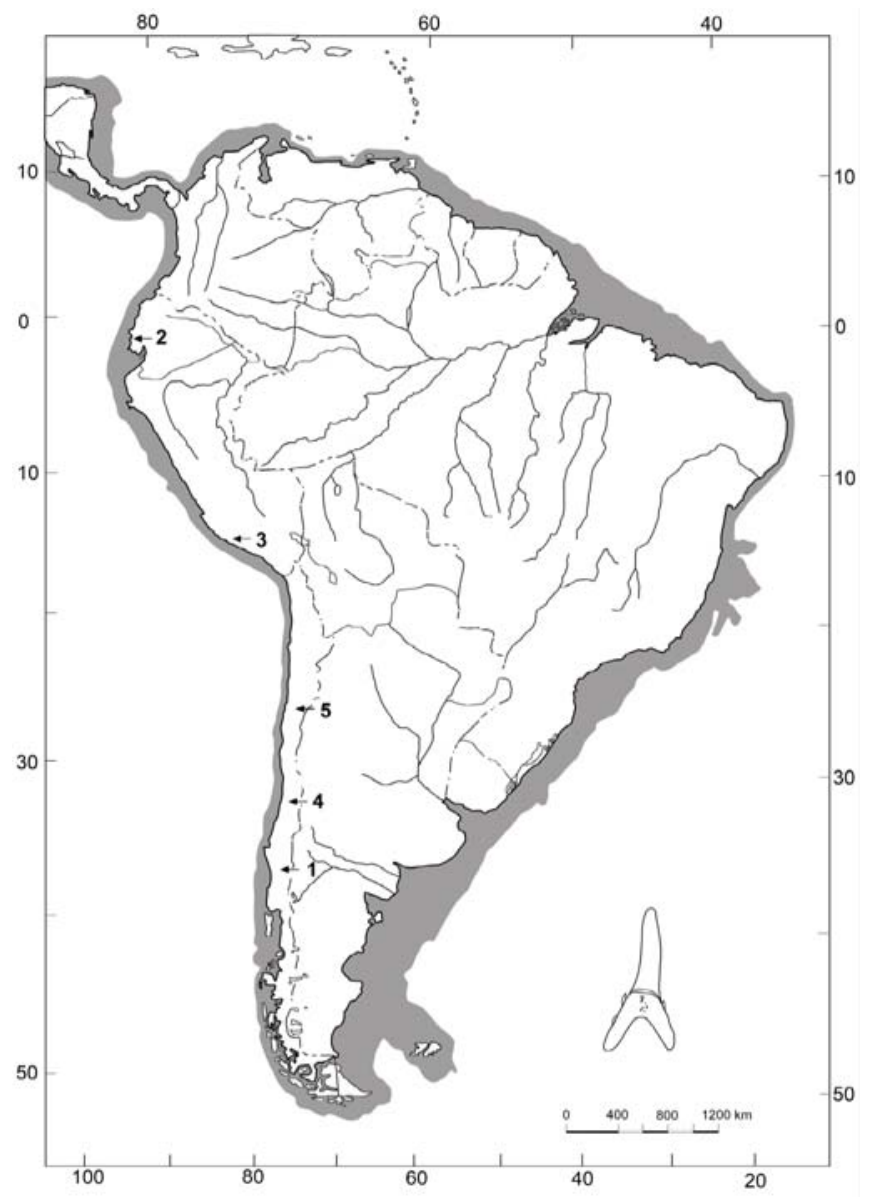

FIG. 2. Localities with fossil odontaspidids in the Pacific coast of South America. 1. Lebu (Chile); 2. Punta La Colorada and Punta La Gorda (Ecuador); 3. Sacaco (Perú); 4. Navidad (Chile); 5. Bahía Inglesa (Chile). The present South American continental shelf is in gray.

\section{ACKNOWLEDGMENTS}

J. Bourdon and R. Purdy (Smithsonian Institution), for valuable information. The reviewers G. Arratia (University of Kansas) and H. Cappetta (Université de Montpellier), for relevant criticism. The Agencia
Nacional de Promoción Científicay Tecnológica, Consejo Nacional de Investigaciones Científicas y Técnicas, and Universidad Nacional de La Plata, Argentina, for partial support for this project.

\section{REFERENCES}

Aalto, K.R.; Miller, W.III. 1999. Sedimentology of the Pliocene Upper Onzole Formation, an inner-trench slope succesion in northwestern Ecuador. Journal of South American Earth Sciences 12: 69-85.
Agassiz, L. 1833-1843. Recherches sur les Poissons Fossiles. Petitpierre, Neuchatel, 390 p.

Agassiz, L. 1842-1846. Nomenclator Zoologicus. Soloduri. Arratia, G.; Cione, A.L. 1996. The fossil fish record of 
Southern South America. In Contributions of Southern South America to Vertebrate Paleontology (Arratia, G.; editor). Münchener Geowissenschaftliche Abhandlungen 30: 9-72.

Beu, A. G.; Griffin, M.; Maxwell, P.A. 1997. Opening of Drake Pasage gateway and Late Miocene to Pleistocene cooling reflected in Southern Ocean molluscan dispersal: evidence from New Zealand and Argentina. Tectonophysics 281: 83-97.

Bianucci, G.; Cantalamessa, G.; Landini, W.; Ragaini, L.; Valleri, G. 1993. Fossil assemblages from the Pliocene of Onzole formation (Esmeraldas, NW Ecuador) and their implications in the Panamic bioprovince evolution. Documents du Laboratoire de Géologie 125: 43-58. Lyon

Cappetta, H. 1987. Chondrichthyes II. Gustav Fischer Verlag: 193. Stuttgart.

Cappetta, H.; Duffin, C.; Zidek, J. 1993. Chondrichthyes. In The Fossil Record (Benton, M.J.; editor). Chapman \& Hall 2: 593-609. London.

Cione, A.L. 1978. Aportes paleoictiológicos al conocimiento de la evolución de las paleotemperaturas en el área austral de América del Sur durante el Cenozoico. Aspectos zoogeográficos y ecológicos conexos. Ameghiniana 15: 183-208.

Cione, A.L.; Azpelicueta, M.M. 2002. An oplegnathid fish from the Miocene of Patagonia. Geobios 35: 367-373.

Cione, A.L.; Reguero, M. 1994. New records of the sharks Isurus and Hexanchus from the Eocene of Seymour Island, Antarctica. Proceedings of the Geologist's Association 105: 1-14.

Cione, A.L.; Tonni, E.P. 1995. Chronostratigraphy and 'Land-mammal ages' in the Cenozoic of southern South America: principles, practices, and the 'Uquian' problem. Journal of Paleontology 69:135-159.

Cione, A.L.; Valle, R.; Rinaldi, C.; Tonni, E.P. 1977. Nota preliminar sobre los pingüinos y tiburones del Terciario inferior de la isla Vicecomodoro Marambio, Antártida. Contribuciones Científicas del Instituto Antártico Argentino 213: 3-21.

Cione, A.L.; Azpelicueta, M.M.; Bond, M.; Carlini, A.; Casciotta, J.R.; Cozzuol, M.A.; de la Fuente, M.; Gasparini, Z.; Goin, F.J.; Noriega, J.I.; Scillato-Yané, G.J.; Soibelzon, L.; Tonni, E.P.; Verzi, D.; Vucetich, M.G. 2000. The Miocene vertebrates from Paraná, eastern Argentina. In El Neógeno de Argentina (Aceñolaza, F.G.; Herbst, R.; editors). Instituto Superior de Correlación Geológica, Serie Correlación Geológica 14: 191-237.

Clapperton, C. 1993. Quaternary geology and geomorphology of South America. Elsevier: 779 p. Amsterdam.

Compagno, L.J.V. 2001. Sharks of the World. An annotated and illustrated catalogue of shark species known to date. Vol. 2. Bullhead, mackerel and carpet sharks (Heterodontiformes, Lamniformes and Orectolobiformes). Fao Species Catalogue for Fishery
Purposes 2 (1), Food and Agriculture Organization of the United Nations. 269 p. Rome.

Cronin, T.; Dowsett, H. 1992. The Pliocene record of climatic change: equator-to-pole biotic response. In Abstracts and Program of the Fifth North American Paleontological Convention. The Paleontological Society, Special Publication 6: 78. Knoxville.

Dalinkevicius, J.A. 1935. On the Fossil Fishes of the Lithuanian Chalk. 1. Selachii. Vytauto Didiojo Universiteto Matemetikos-Gamtos Fakulteto Darbai 9: 3-63.

de Muizon, C. 1981. Les vertébrés fossiles de la Formation Pisco (Pérou). Première partie. Mémoires du Institut Français d'Études Andines 6:1-150.

de Muizon, C.; DeVries,T.J. 1985. Geology and paleontology of late Cenozoic marine deposits in the Sacaco area (Peru). Geologische Rundschau 74 (3): 547-563.

Duque-Caro, H. 1990. Neogene stratigraphy, paleoceanography and paleobiogeography in northwest South America and the evolution of the Panama seaway. Palaeogeography, Palaeoclimatology, Palaeoecology 77: 203-234.

Glückman, L.S. 1964. Sharks of Paleogene of stratigraphic significance. Nauka Press: 229. Moskow-San Petersbourg.

Hagelberg, T.K. 1996. Equatorial Pacific sea surface temperatures, faunal patterns, and carbonate burial during the Pliocene. Marine Micropalaeontology 27: 63-84.

Ibaraki, M. 1997. Closing of the Central American Seaway and Neogene coastal upwelling along the Pacific coast of South America. Tectonophysics 281: 99104.

Kim, J.H.; Schneider, V.V.; Hebbeln, D.; Müller, P.J.; Wefer, G. 2002. Last deglacial sea-surface temperature evolution in the Southeast Pacific compared to climate changes on the South American continent. Quaternary Science Reviews 21: 2085-2097.

Lambeck, K.; Esat, T.; Potter, E.K. 2002. Links between climate and sea levels for the past three million years. Nature 419: 199-206.

Leriche, M. 1936. Sur l'importance des squales fossiles dans l'établissement des synchronismes de formations à grandes distances et sur la répartition stratigraphique et géographique de quelques espèces tertiaires. Mémoires du Muséum Royal d'Histoire Naturelle de Belgique 3: 739-773.

Long, D. 1992. The shark fauna from La Meseta Formation (Eocene), Seymour Island, Antarctic Peninsula. Journal of Vertebrate Paleontology 12: 11-32.

Longbottom, A.E. 1979. Miocene sharks' teeth from Ecuador. Bulletin of the British Museum (Natural History), 32: $57-70$.

López, R. 1964. Problemas de la distribución geográfica de los peces marinos suramericanos. Boletín del Instituto de Biología Marina de Mar del Plata 7: 57-63. 
Loubere, P. 2002. Remote vs. local control of changes in eastern equatorial Pacific bioproductivity from the Last Glacial Maximum to the Present. Global and Planetary Change 35: 113-126.

Lucifora, L.O.; Cione, A.L.; Menni, R.C.; Escalante, A.H. 2003. Tooth row counts, vicariance, and the distribution of the sand tiger shark, Carcharias taurus. Ecography 26: 567-572.

Molina-Cruz, A.; Herguera, J.C. 2002. Paleoceanographic evolution of backwater in the Nazca region, southeastern Pacific, during late Pleistocene. Revista Mexicana de Ciencias Geológicas 19: 252-259.

Moy, C.M.; Selzer, G.O.; Rodbell, D.; Anderson, D. 2002. Variability of El Niño/Southern Oscillation activity at millennial timescales during the Holocene epoch. Nature 420: 162-165.

Oliver-Schneider, C. 1936. Comentarios sobre los peces fósiles de Chile. Revista Chilena de Historia Natural, 40: 306-323.

Rafinesque, C.S. 1810. Caratteri di alcuni nuovi generi e nuevi spece di animali e piante della Sicilia 2: 71-105. Palermo.

Reif, W.E.; Saure, C. 1987. Shark biogeography: vicariance is not even half the story. Neus Jahrbuch für Geologie und Paläontologie, Abhandlungen 175: 117.

Rohling, E.J.; Fenton, M.; Jorissent, F.; Bertrand, P.; Ganssent, G.; Caulets, J. 1998. Magnitudes of sealevel lowstands of the past 500,000 years. Nature 394: 162-165.

Smith, A.B.; Gale, A.S.; Monks, N.E. 2001. Sea-level change and rock-record bias in the Cretaceous: a problem for extinction and biodiversity studies. Paleobiology 27: 241-253.

Siverson, S. 1995. Revision of the Danian cow sharks, sand tiger sharks, and goblin sharks (Hexanchidae, Odontaspididae, and Mitsukurinidae) from southern Sweden. Journal of Vertebrate Paleontology 15: 1-12.

Suárez, M.; Encinas, A. 2002. Vertebrados marinos del Miembro inferior de la Formación Navidad (Mioceno temprano), Chile Central. In Congreso Latinoamericano de Paleontología de Vertebrados, No. 1, Resúmenes: 51-52. Santiago, Chile.

Suárez, M.; Chávez, M.; Marquardt, C. 2002. Nuevos hallazgos de vertebrados marinos en la Formación Bahía Inglesa (Mioceno-Plioceno), Caldera, Norte de Chile. In Congreso Latinoamericano de Paleontología de Vertebrados, No. 1, Resúmenes: 50-51. Santiago, Chile.

Suárez, M.; Lamilla, J.; Marquardt, C. 2004. Peces Chimaeriformes (Chondrichthyes, Holocephali) del Neógeno de la Formación Bahía Inglesa (Atacama, Chile). Revista Geológica de Chile 31 (1): 105-118.

Tsuchi, R. 2002. Neogene evolution of surface marine climate in the Pacific and notes on related events. Revista Mexicana de Ciencias Geológicas 19: 260270.

Walsh, S.A.; Hume, J.P. 2001. A new Neogene marine avian assemblage from North-Central Chile. Journal of Vertebrate Paleontology 21: 484-491.

White, E.I. 1931. The vertebrate faunas of the English Eocene. I. From the Thanet sands to the basement bed of the London Clay. British Museum (Natural History): 121 p. London. 